\title{
Preservice teachers' conceptions about animals and particularly about spiders
}

\section{Carmen Urones Jambrina, José Manuel Vacas, Miguel Sánchez-Barbudo}

School of Education, University of Salamanca

\section{Spain}

Correspondence: Carmen Urones Jambrina. Dpto. Didáctica Matemáticas y Ciencias Experimentales, Facultad de Educación, Universidad de Salamanca. Paseo Canalejas, 169. E-37008 SALAMANCA (Spain). E-mail: uronesc@usal.es

(C) Education \& Psychology $\mathrm{I}+\mathrm{D}+\mathrm{i}$ and Editorial EOS (Spain) 


\begin{abstract}
Introduction. This article explores the scientific ideas and alternative conceptions that preservice teachers have regarding animal classification and spiders in particular.

Method. The study involved 40 pre-service teachers of elementary education in Spain and the data was collected by means of questionnaires, descriptions and drawings. The students completed all the tests proposed in this research at the beginning of class sessions.

Results. We found several misconceptions, some of them consistent with children's interpretations. The results show that the majority had great difficulty distinguishing between vertebrates and invertebrates, and although all the participants said they were familiar with spiders the results indicate that the majority have scarce knowledge of them.

Discussion and conclusions. These prospective teachers may begin teaching at school without really having a good understanding of living things. These results should serve to reformulate the current development of the curriculum on invertebrates in Spain and foster practical instruction about living organisms for future teachers.
\end{abstract}

Keywords: Animals, misconceptions, natural science education, preservice teacher Received: 03/30/10 Initial Acceptance: 04/20/10 Definitive Acceptance: 07/27/10 


\section{Ideas de los futuros maestros sobre los animales y las arañas en particular}

\section{Resumen}

Introducción. Este artículo explora las concepciones alternativas e ideas científicas que los futuros maestros poseen sobre la clasificación animal y las arañas en particular.

Método. El estudio involucró a 40 estudiantes universitarios españoles de la titulación de maestro de educación infantil. Los datos se obtuvieron con cuestionarios, de preguntas abiertas y cerradas, dibujos y descripciones extensas sobre algunos seres vivos. Los estudiantes completaron todas las pruebas propuestas al comienzo de las sesiones de clase.

Resultados. Se ha encontrado que los futuros maestros presentan varias concepciones erróneas coincidentes con las que manifiestan los niños, por ejemplo la mayoría tiene gran dificultad en distinguir entre vertebrados e invertebrados. Y aunque todos los participantes dicen conocer a las arañas, los resultados indican que poseen conocimientos escasos, que responden a estereotipos y no a concepciones científicas.

Discusión y conclusiones. Estos futuros maestros pueden empezar a enseñar en la escuela sin tener una buena comprensión de los seres vivos. Estos resultados deben servir para replantearse el desarrollo actual del currículum en España y potenciar la instrucción práctica de los futuros profesores sobre los seres vivos.

Palabras Clave: Animales, concepciones alternativas, educación en ciencias naturales, formación de maestros.

Recibido: 30/03/10 Aceptación Inicial: 20/04/10 Aceptación Definitiva: 27/07/10 


\section{Introduction}

The importance of biodiversity and its conservation should form part of the scientific knowledge of every citizen. That is why the presence of content relating to living organisms in general is a constant throughout the curriculum for basic education. Students should understand from the very beginning of their education that success in conservation requires an understanding of the interactions between wildlife and human populations, so that they can confront the challenge of upholding and improving future quality of life. However, research carried out in this field in different countries shows that students, whether they are in elementary, secondary or higher education, have serious problems in recognizing what an animal is (Bell \& Barker, 1982; Trowbridge \& Mintzes, 1985), in classifying animals (Braund, 1991; Kattmann, 2001; Yen, Yao, \& Mintzes, 2007) and in classifying different groups of animals (vertebrate/ invertebrate: Braund, 1998; Trowbridge \& Mintzes, 1988). Several research studies have dealt with specific groups of animals, especially vertebrates (Tunnicliffe \& Reiss, 1999), birds (Prokop, Kubiatko, \& Fančovičová, 2007), amphibians and reptiles (Yen, Yao, \& Chiu, 2004), while fewer have concentrated on insects or spiders (Barrow, 2002; Shepardson, 1997, 2002).

Spiders are one of many animals (along with bats, snakes, wolves, etc.) about which a false image has been created based on myths and legends that are socially transmitted (Davey, 1994; Melic, 2002). Many people are afraid of or disgusted by spiders, but this fear and disgust have nothing to do with biological reality. In fact, the Araneae are shy and peaceful animals, and very beneficial to humankind, because they control insect populations on which they mostly feed. Only a very few species may pose a danger to people because of their venom. They are also ubiquists, that is, they found are everywhere (Ruppert, Fox, \& Barnes, 2004). Their populations are very large and they play a significant role in all ecosystems; with more than 41,000 species (Platnick, 2010), spiders occupy seventh place in the planet's biodiversity (Coddington \& Levi, 1991) and they should figure prominently in conservation programs (Redak, 2000). And yet despite the great significance of spiders, few studies have examined children's biological perceptions (Biddulph, 1982; Prokop \& Tunnicliffe, 2008; Shepardson, 2002) or high school students' attitudes towards spiders (Prokop, Tolarovicova, Camerik, \& Peterkova, 2009), let alone those of prospective teachers. As far as we are aware, 
there is only the preliminary study of Urones (2008), which revealed that their knowledge of spiders taxonomy was deficient.

Since the basic scientific training of children is in the hands of their teachers, it is highly important to know their level of competence. Without an understanding of the basic biological concepts it is impossible to approach living organisms scientifically, much less transmit that knowledge (Campanario, 1998; Harlen, 2003; Thurston, Grant, \& Topping, 2006). The knowledge of students' conceptions has been shown to be fundamental in the implementation of significant learning (Ausubel, Novak, \& Hanesian, 1983). We wished to know what scientific information future teachers have about animal diversity and, according to the results, how to better design our teaching activities by making them significant and functional. Apart from learning what students do not know, our aim with this research was to bring to light some positive points about what they do know, the biological concepts they understand and how to apply them.

From the science education perspective, myths or alternative conceptions are especially important in the case of the least popular animals such as spiders, insects or snakes, and we do not really know the true extent of university students' knowledge about them. Because learners' concepts and/or behaviour towards these animals can be influenced by negative attitudes (Knight, 2008; Prokop \& Tunnicliffe, 2008), owing to the fear, phobia and disgust that a good part of society feels towards spiders (Kindt \& Brosschot, 1999).

We have focused this research study on the scientific ideas and alternative conceptions that prospective elementary school teachers in Spain have regarding animal classification and spiders in particular and the implications these ideas have on their own educational training regarding children's scientific ideas. It is of interest to learn what image prospective teachers build of animals, and particularly of spiders, what values they show towards them, and what factors can affect this. In the present study we wish to show the extent of prospective teachers' knowledge of spider diversity, since this could be one of the factors having an influence on the ideas of their future pupils. 


\section{Method}

\section{Participants}

The study was conducted at the University of Salamanca's School of Education (Spain), during the 2007-08 academic year, with prospective elementary school teachers who in the future would be responsible for helping young children (aged 3-6) take their first steps in the scientific understanding of their environment and the living organisms that inhabit it. Second year students were chosen because it is in this year of study when they have their first and only core subject in the Natural Sciences. This subject is called "Knowledge of the Natural Environment and its Teaching," and has 45 hours (35 theory and 10 practical) in the first semester.

The age of the participants ranged between 19 and 24 (97.5\%), the average age was 21 , and most were female $(85.0 \%)$, which was why gender differences did not form part of the study. The most of the students had chosen to specialize in the humanities at the uppersecondary level; only 7.5\% had studied Natural and Health Sciences. As regards subjects taken in Natural Sciences, $80 \%$ chose Biology and Geology as their elective subjects for 4th year of lower secondary, whereas the other $20 \%$ had studied a science subject which included biology for the last time in third year of lower secondary, at the age of 14.

\section{Instruments}

The information was collected through several means, tested from previous research (Urones, 2008):

1. An open questionnaire that inquired about the species that pre-service teachers have knowledge of in certain animal groups that are characteristic of elementary education, such as mammals, birds, insects and invertebrates. We asked the prospective teachers to give us the names of three species that they knew and that belonged to these groups of animals.

2. The participants had to:

- Write a description including the most determinant characteristics for an animal to be included in the Order Araneae (spiders). 
- Draw what a spider looks like on the outside.

- Closed-ended multiple-choice questions on five dimensions in the morphology and biology of spiders (parts of the body, number of moving limbs, eyes, silk and use of spiderwebs, and venom).

3. Open-ended and closed-ended multiple choice, regarding basic facts about the ecology of spiders: their role within the food chain: what they eat, trophic dynamics (autotrophs or heterotrophs), feeding behaviors (producers, consumers or decomposers), choose what spiders eat from a list of several potential nutrients, and who their natural enemies are.

4. Open-ended questions about relationships between spiders and humans (Benefits, harm, attitudes towards spiders, the consequences of the disappearance of spiders and protective measures).

\section{Procedure}

The information was collected in the classroom. The study group consisted of 40 prospective teachers those who completed all the tests proposed in this research (questionnaires, descriptions and drawings) at the beginning of class sessions. They also provided demographic information, including age, gender, and secondary school records to completing the questionnaires. Permission was obtained from all the participants to use their answers in the study and the participants were informed that all results were confidential.

\section{Design and statistical analysis}

The responses to the closed survey items were analyzed quantitatively (MS Excel 2003 and SPSS), and the descriptions, drawings and open-ended questions were analyzed qualitatively and quantitatively with a content analysis following the same schema used for the data obtained from the closed questions. We analyzed what the prospective teachers knew according to the data collected and what they should know according to the compulsory contents established by Spanish legislation on education: the common curricula for Pre-School, Elementary and Secondary levels (Spanish Ministry of Education and Science [MEC] 2006, $2007 \mathrm{a}, \mathrm{b})$ and the contents of the some textbooks for compulsory Education from different publishers widely used in Spanish schools. 


\section{Results}

\section{What animals are the students familiar with?}

1.1. Birds: All the prospective teachers knew many names of animals belonging to the class of birds, for which almost all knew three names and made no mistakes. The most popular species that are mentioned (Table 1) are the predominant ones in urban ecosystems (e.g., white stork, rock dove). Most of the students lived in cities and in the city the birds are highly visible.

Table 1. Most frequently named Birds

\begin{tabular}{cc}
\hline Responses & $\%$ \\
\hline White Stork & 72.5 \\
Rock Dove & 57.5 \\
House Sparrow & 30 \\
Swallow & 27.5 \\
Duck & 20 \\
Goldfinch & 17.5 \\
Eagle & 7.5 \\
Owl & 5 \\
No answer & 0 \\
\hline
\end{tabular}

1.2. Mammals: In this respect the prospective teachers appeared to have an acceptable level of knowledge of mammals. The best known species corresponded to pets, such as dogs and cats (Table 2) and, to a lesser extent, farm animals (cow, horse). Only a few preservice teachers ( $2.5 \%$ percent) chose humans as an example of mammals.

Table 2. Most frequently named Mammals

\begin{tabular}{cc}
\hline Responses & $\%$ \\
\hline Dog & 77.5 \\
Cat & 70 \\
Cow/ Bull & 27.5 \\
Horse & 20 \\
Pig & 15 \\
Sheep & 12.5 \\
Mouse & 10 \\
Rat & 5 \\
No answer & 0 \\
\hline
\end{tabular}


1.3. Insects: Regarding the insect class (Table 3), the prospective teachers had scant knowledge of the different species, even though insects make up the most diverse group. Twenty percent of the participants mistakenly included spiders among the insects, which we shall go into more deeply in a subsequent section. And 7.5\% percent included terms as imprecise as "worm" (earthworm or silk worm?).

Among the correct answers, the species most named were the fly and the mosquito $(85 \%)$, followed by the ant (42.5\%), all of which are very common species. For other insects they used very broad names that correspondes to orders and they included a large number of species (e.g. butterfly, grasshopper, etc.), the same as their responses to other invertebrates. This was quite the opposite of the very specific names used by the prospective teachers in the case of birds and mammals (e.g. white stork, house sparrow, etc.), a reflection on the direct experiences they had with these animals.

Table 3. Most frequently named Insects

\begin{tabular}{cc}
\hline Responses & $\%$ \\
\hline Fly & 62.5 \\
Mosquito & 22.5 \\
Ant & 42.5 \\
Cockroach & 22.5 \\
Cricket & 17.5 \\
Grasshopper & 17.5 \\
Bee & 10 \\
Wasp & 10 \\
Dragonfly & 10 \\
Butterfly & 7.5 \\
Moth & 7.5 \\
Worm (imprecise) & 7.5 \\
Spider (wrong) & 20 \\
No answer & 0 \\
\hline
\end{tabular}

1.4. Invertebrates: The preservice teachers had much less knowledge of the invertebrates group, animals without backbones, than they did of vertebrates (see Table 4). Seven point five percent of the students were unable to write down a single name, and mistakes were predominant among those that answered. Seventy percent of the prospective teachers included names of vertebrate species in the invertebrates group: 62.5\% named reptiles (snake, serpent, viper and lizard); who had included reptiles among the invertebrates also cited names of insects. 
The participants also mistakenly included amphibians and birds. Thus, the prospective teachers had great difficulty in distinguishing invertebrates from vertebrates.

Among the invertebrates, those most named were the Annelids (e.g. earthworm), the Mollusks (snail) and the Arthropods (insects, myriapods and arachnids, e.g. spider, 10\%). A high percentage of responses (32.5\%) included as a species the rather imprecise category of "worm." It is a word also used in the school textbooks but always as a compound: roundworms, flatworms, and so on; it is also used in everyday language in an imprecise way that can lead to mistakes. We have already shown that one group of participants referred to worms as part of the insect category (see Table 3).

Table 4. Most frequently named Invertebrates

\begin{tabular}{cc}
\hline Responses & $\%$ \\
\hline Earthworm & 50 \\
Worm & 32.5 \\
Insects & 30 \\
Snail & 22.5 \\
Centipede & 10 \\
Spider & 10 \\
Slug & 5 \\
Reptiles (wrong) & 62.5 \\
Amphibians (wrong) & 5 \\
No answer & 7.5 \\
\hline
\end{tabular}

2. Are spiders animals that students are familiar with? What is a spider like?

One hundred percent of the participants wrote the description asked for. All the prospective teachers were familiar with spiders, which can be found in the local environment, and $97.5 \%$ drew a spider, showing that for them spiders are clearly recognizable creatures. But, do they really know what a spider is? In this research we inquired into the prospective teachers' morphological knowledge of spiders, regarding those characteristics that allow us to recognize one as such by means of descriptions, drawings (Figs. 1-12) and close-ended questions (see some Table 5). 

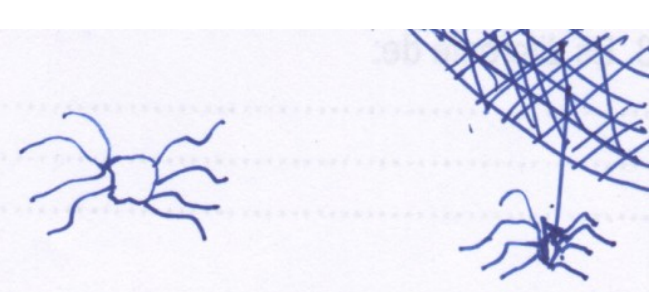

1

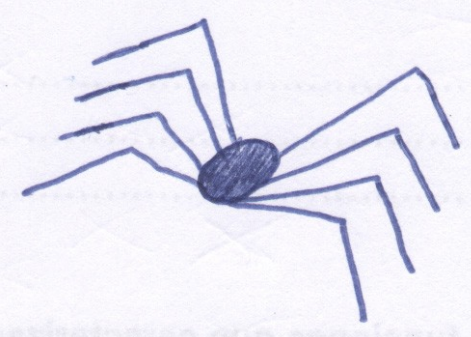

4

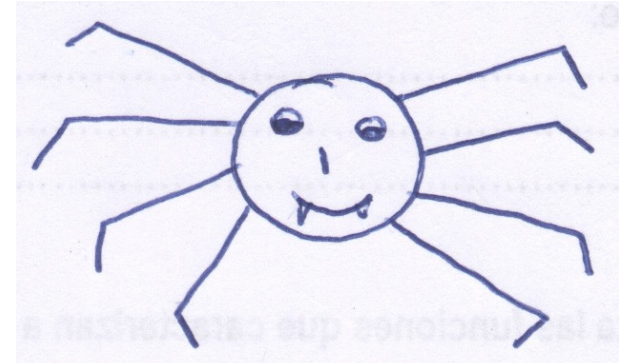

7

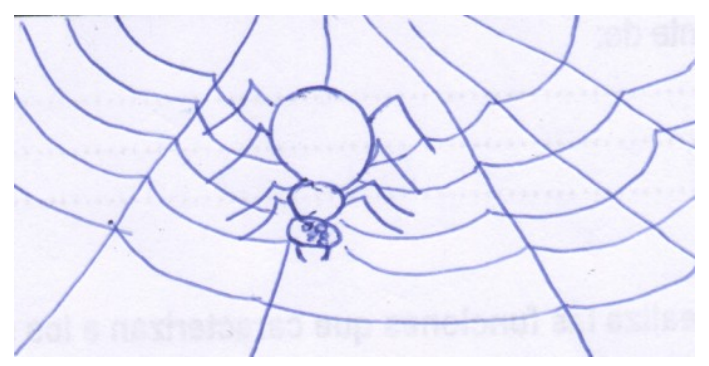

10

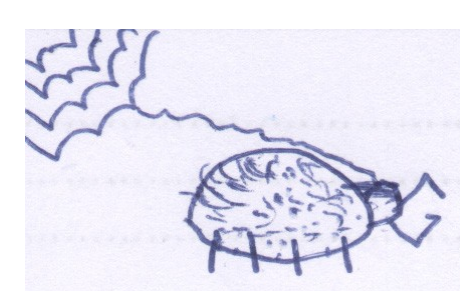

2

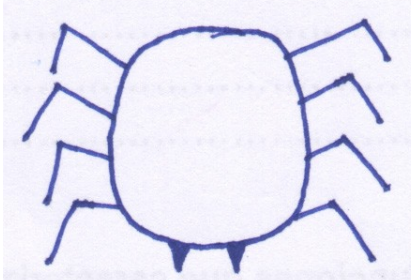

5

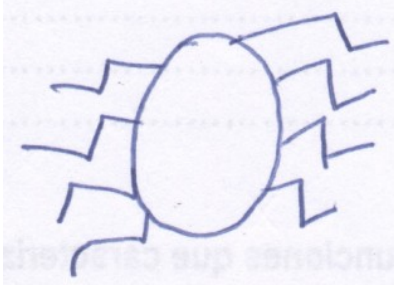

8

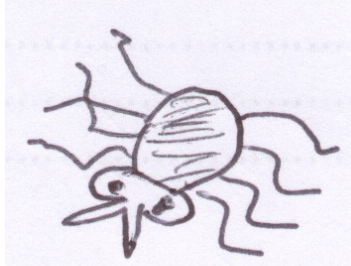

11

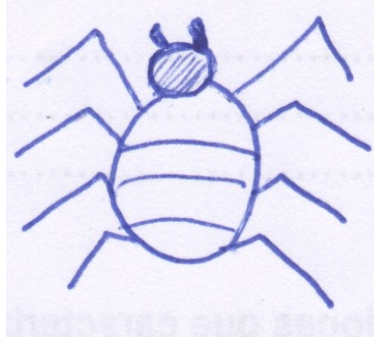

3

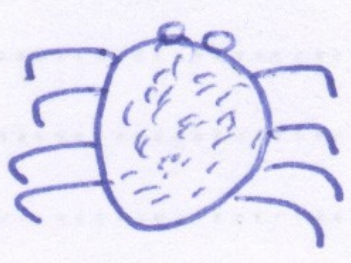

6

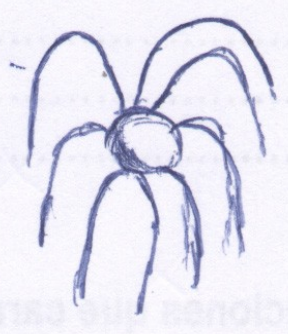

9

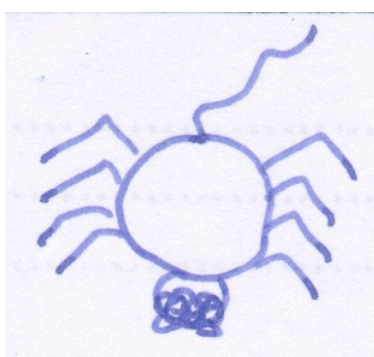

12

Figures $1-12$. Drawings made by prospective teachers of the morphology of the spider

2.1. The body: In their written descriptions, a very few students (5\%) answered that a spider's body is divided into two parts. Although in their drawings some students did distinguish them $(35 \%)$, for some of them the parts were of similar size, but in general the abdomen was larger (Figs. 2, 3, 12). In the closed questions, 37.5\% chose two body segments. In the description they mistakenly affirm that spiders have a body that is "round like a ball" (15\%) and more 
than half of the sample (60\%) drew an undivided body, spherical or ovoid (Figs. 4, 6, 7, 8, 9) and even square in shape (Figs. 1, 5), with long legs, as can be seen in the students' drawings (Figs. 1, 4, 7). In the closed questions $45 \%$ chose one body segment. This image of a fused body corresponds to other orders of arachnids, either with ticks and mites or with opiliones (harvestman, daddy longlegs), which are arachnids like spiders but with a prosoma and opisthosoma united throughout their whole width and many with long legs.

Other students (2.5\%) wrongly divided the body into 3 parts (Fig. 10), which is actually a characteristic of insects. In their written descriptions, 30\% of the students erroneously described spiders as "insects," even though $20 \%$ had included them in this taxonomic group (Table 3).

The prospective teachers also used some attributes in their descriptions and drawings that did not serve to define spiders and lacked taxonomic value: for example, the body color, which in reality varies widely in the order, is depicted by many participants (35\%) as dark: brown or black (Figs. 4, 11). Another characteristic is the presence of hair; 25\% drew spiders with hair all over them (Figs. 2, 6) and $42.5 \%$ say they have hair everywhere. Finally, in their descriptions some respondents devoted a specific adjective to spiders: they called them "ugly."

2.2. The legs: The best known characteristic of spiders is that they have eight moving limbs. Eighty percent of the students drew eight legs and $72.5 \%$ included this fact in their written descriptions. Some made a mistake and drew six legs, the number corresponding to insects $(12.5 \%)$, or even ten legs, corresponding to the decapod crustaceans $(2.5 \%)$. In general, in their written descriptions the prospective teachers considered the legs to be much longer than the body (22.5\% stated that spiders had long legs and $17.5 \%$ that they had a small body). Spider legs extend exclusively from the prosoma, but most students drew them along the whole body. Each leg is made up of seven articulated segments or joints (which is why they belong to the phylum Arthropoda). Not one of the prospective teachers drew the right number of joints: $52.5 \%$ drew 2 joints (Figs. 3, 4, etc.) and $7.5 \%$ drew 3 joints (Fig. 8). But for 35\% of the students the legs are curved and have no joints (Figs. 1, 9). This aspect is similar to that found in certain works of art, such as the famous "Maman" sculptures by L. Bourgeois which have been exhibited in different cities of the world. Many prospective teachers, although they 
drew a large number of legs, also drew the spider moving on only two limbs, what could be called "human type movement" or bipedal movement (Fig. 8).

2.3. The eyes: Only in the closed questions did $12.5 \%$ select the option 8 eyes. In the description, $10 \%$ did not specify a number, saying that "spiders have several eyes." More than half the students gave them 2 eyes (Figs. 6, 7, 11), 7.5\% 4 eyes (Fig. 10), and 5\% wrongly gave them 10 eyes. Most striking were the human stereotypes where the spiders had eyelids and even noses (Fig. 7).

2.4. Silk and spiderwebs: All spiders produce silk and the silk-secreting glands, called spinnerets, are located on the lower end of the opisthosoma. In their drawings, $20 \%$ of our students referred to the possession of silk. Some correctly drew a thread of silk coming out of the lower end of the opisthosoma (12.5\%, Fig. 10), although others (7.5\%, Fig. 2) mistakenly had the silk coming out of the spider's mouth. For one student the silk comes out of two places at once: the prosoma and the abdomen (Fig. 12).

Most of the prospective teachers knew that spiders often build silk traps to catch prey, or spiderwebs ( $90 \%$ in the closed questions and $22.5 \%$ in their drawings). Some drew them as a circle with spokes (Fig. 10), or in an irregular shape (Fig. 1).

2.5. Venom: Most spiders produce venom for hunting, but only in some very limited cases can they inject humans and cause harm. In the closed questions, $5 \%$ of the prospective teachers stated that all spiders produce venom and $75 \%$ that they did not. This aspect was of concern to the participants since $10 \%$ included it in their description. Some of them persisted with more mistakes and said spiders have a stinger like bees.

The presence of chelicerae, pointed appendages that hold the venom glands were not easily recognized by the students; $32.5 \%$ of them drew pincers (fangs) in the mouth (Fig. 5), but some drew fangs, even situating them in a human type mouth (Fig. 7). Other students reaffirmed in their drawings their mistake of considering spiders as insects, and thus drew antennae on the spider's head, and stripes on the body as if it were a wasp (Fig. 3), or stingerlike proboscis as if it were a mosquito (Fig. 11). 
Besides limbs and chelicerae, spiders have another pair of appendages situated between them, called pedipalps, the same as in other arachnids. The pedipalps, similar to legs, appeared only rarely in the drawings (Fig. 1). Their function is mainly sensorial, but in the case of the males they are enlarged and carry the copulating system, which the male must introduce into the female genitalia. None of the students mentioned these appendages or their importance in their written descriptions or answers to questions.

Table 5. Percentage of responses to the Morphology questions: What is a spider like? A: written descriptions, $B$ : drawing, $C$ : closed-ended questions

\begin{tabular}{ccccc}
\hline Question & Responses & $\% \mathrm{~A}$ & $\% \mathrm{~B}$ & $\% \mathrm{C}$ \\
\hline The body is divided into & 2 parts & 5 & 35 & 37.5 \\
& 1 part (wrong) & 15 & 60 & 45 \\
& 3 parts (wrong) & 0 & 2.5 & 2.5 \\
Moving legs & Don't know & 80 & 2.5 & 15 \\
& 8 legs & 72.5 & 80 & 80 \\
& 4 legs (wrong) & 2.5 & 0 & 5 \\
& 6 legs (wrong) & 0 & 12.5 & 2.5 \\
& 10 legs (wrong) & 0 & 2.5 & 0 \\
& Several (imprecise) & 12.5 & 2.5 & 7.5 \\
& Don't know & 12.5 & 2.5 & 5 \\
The eyes & 8 usually & 0 & 0 & 12.5 \\
& 2 eyes (rare) & 2.5 & 27.5 & 55 \\
& 4 eyes (rare) & 2.5 & 2.5 & 7.5 \\
& 10 eyes (wrong) & 0 & 0 & 5 \\
& Several (imprecise) & 10 & 5 & 5 \\
Produce silk & Don't know & 85 & 65 & 15 \\
& Yes & 0 & 20 & 57.5 \\
& No & 0 & 0 & 0 \\
All use spiderwebs & Don't know & 100 & 80 & 42.5 \\
& Yes & 20 & 22.5 & 90 \\
& No & 0 & 0 & 0 \\
All have venom & Don't know & 80 & 77.5 & 10 \\
& Yes & 10 & 0 & 5 \\
& No & 0 & 0 & 75 \\
& Don't know & 90 & & 20 \\
& Chelicerae & 5 & 32.5 & 5 \\
& Don't know & 0 & 2.5 & 2.5 \\
& & 95 & 65 & 92.5 \\
\hline \multirow{4}{*}{ Venom where? } & & &
\end{tabular}


3. Identify the spider's role within the food chain.

3.1. What do spiders eat? Almost all the participants (95\%) responded that spiders eat insects, or that they usually catch smaller animals. Among these wrongly, 5\% also said that they eat leaves and $2.5 \%$ blood. Five percent gave no answer.

3.2. Trophic dynamics: Are spiders autotrophs or heterotrophs? $7.5 \%$ incorrectly stated that spiders are autotrophs; half of them (45\%) recognized that they are heterotrophs and $47.5 \%$ gave no answer. From a list: $32.5 \%$ correctly chose predators, spiders eat animals, and 5\% incorrectly chose herbivores and 7.5\% decomposers. Without an understanding of the basic biological concepts it is impossible to approach living organisms scientifically, much less transmit that knowledge.

3.3. Feeding behaviors. Are spiders producers or consumers in ecosystems? $40 \%$ of the participants did not understand the distinction between primary producers and consumers, $47.5 \%$ recognized that they are consumers. These basic concepts are the key to understanding other more complex concepts in biology and ecology, and the results showed that preservice teachers begin their studies without having assimilated what is considered to be a basic and fundamental knowledge of ecology which the school system was supposed to have transmitted to them.

3.4. Choose what spiders eat from a list of several potential nutrients. Notwithstanding the answer to the question above, $85 \%$ of preservice teachers selected insects and $17 \%$ plants (leaves, seeds, fruit, etc.), $22.5 \%$ of the participants erroneously affirmed that they eat humus and earth and 5\% even chose (incorrectly) that spiders eat blood.

3.5. What are the natural enemies of spiders? The prospective teachers answered vertebrates (snakes, frogs, birds...) (25\%) and big insects (10\%), although a surprising $22.5 \%$ chose humans among their "natural" enemies. This last result indicates that many of the participants think that humans naturally wish to do them harm, that spiders are living beings who are enemies of humans. Thus, understanding of the role represented by spiders in nature is meagre. 
4.1. Are spiders useful to humans? For $42.5 \%$ spiders can be somewhat beneficial for human beings' quality of life, but not in a very important way. Thirty percent of the students wrote that spiders are used as pets in terrariums, although the people who have them are thought to be "freaky," $10 \%$ said that in some countries they serve as food, and less frequently they thought that they are used as laboratory animals, that their venom is used in medicine, or that industry can use their silk. In their written descriptions, no prospective teachers referred to the fact that spiders are useful to humans.

4.2. Are spiders harmful to humans? For $77.5 \%$ spiders are harmful to human beings and a surprising $10 \%$ included in their written descriptions, as one of the most important characteristics for determining that an animal belongs to the order Araneae, that "spiders are dangerous to man." For $22.5 \%$ of them, incorrectly, some spiders cause diseases. Others thought that they are bothersome or repulsive, and some were of the opinion that they "are dirty": not that they live in dirty places but that they produce the filth.

4.3. What is your attitude when you see a spider? In this research the spiders were viewed negatively. One sentence summarizes the feelings of the majority: "When I see them I kill them indiscriminately." They do not take into consideration the ecological viewpoint of the important role these animals play in ecosystems. Not one student held a positive view of spiders.

4.4. What would be the environmental consequences of indiscriminate hunting of spiders? Fifty-five percent of the participants said that killing spiders would have no consequences. Only a very few (7.5\%) answered that the food chains would be affected and $12.5 \%$ said that there could be infestations of other animals (especially insects in houses). The rest of the sample said that there would be general consequences, such as pollution of the environment $(10 \%)$ or the extinction of species, but some added that "this wouldn't include spiders, that is rare" $(20 \%)$.

4.5. What is needed to protect spider species? Eighty percent of the prospective teachers said that spiders do not need any protective measures. 


\section{Discussion and Conclusions}

The results of this research suggest that prospective teachers show scant knowledge of animal classification, particularly with regard to invertebrates and especially spiders. And birds and mammals were the best known animals. This is consistent with children' ideas (Barrow, 2002; Braund, 1991, 1998; Prokop et al., 2008; Shepardson, 2002; Trowbridge \& Mintzes, 1985, 1988; Yen et al., 2007).

The class of birds is the most well-known group of living organisms, this is in agreement with Prokop et al. (2007) who confirmed that the majority of older children correctly identified birds. Second place was occupied by mammals which corresponds to bird species in urban ecosystems and pet mammals. They used familiar animals living close by as examples, and this was similar to findings with children living in urban environments, as occured in studies done with students of different ages and different cultures in urban environments (Greece: Karapantsios, Bouskou, \& Balouktsis, 1999; Slovakia: Prokop, Prokop, \& Tunnicliffe, 2008; or Taiwan: Yen et al., 2007). Unlike aboriginal children in China who used mainly examples of the animals they saw on TV or in movies, this indicates that the aboriginal children either lacked confidence in their own life experience, or were misled by mainstream culture (Chen \& Ku, 1998).

In our study only a few preservice teachers chose humans as an example of mammals. Previous research into children's ideas found that a high percentage of 5-10 year old students think that humans are not animals (Chen \& Ku, 1998).

The results show that the preservice teachers are familiar with few insect species. Insects alone make up more than half of all known life forms (Ruppert et al., 2004). Twenty percent of the participants mistakenly included spiders among the insects, a common error in children (Shepardson, 2002). And 7.5\% percent included something as imprecise as "worm" (earthworm or silk worm?); many of the students involved had owned or at least seen silk worms as children, an experience which may be at the origin of this preconception. The preservice teachers' concept of insects was consistent with children's interpretations as "animals that have small size, many feet, can crawl and live on land" (Chen \& Hu, 1998). 
The group of invertebrates was the least well-known group. Many prospective teachers included names of vertebrate species in the invertebrates group: $62.5 \%$ named reptiles (snake, serpent, viper and lizard). This mistake is common in children since these animals do not have limbs (Braund 1998), the criterion of movement when classifying animals is especially important for younger children (Osborne \& Freyberg, 1985). We had to ask ourselves if it was possible that they did not understand the term "invertebrate" or if they had actually read the question wrong and thought we were asking for other classes of vertebrates. Upon closer analysis of their answers it was seen that those who had included reptiles among the invertebrates also cited names of insects. If they included a vertebrate and an insect in the same category, then the above hypothesis is incorrect. Therefore, they did not misinterpret the question; what actually happened was that a large number of the participants did not know the meaning of invertebrate, this is the same as was found in previous research work (Trowbridge \& Mintzes, 1985, 1988; Yen et al., 2007).

Thus, the prospective teachers had great difficulty in distinguishing invertebrates from vertebrates, and their taxonomic knowledge of the invertebrates, especially arthropods in their immediate environment, was poor and to a great extent mistaken, even though the invertebrates are a very important group for the functioning of ecosystems (Ruppert et al., 2004). Nevertheless, the presence of content relating to living organisms in general has been constant throughout their schooling. A review of the Spanish educational system shows that starting in pre-school, curriculum content relating to biodiversity is gradually presented. Groups such as domestic and wild animals or vertebrate and invertebrate animals are studied, and are later dealt with more in detail as the students move through all the levels of elementary education. All of this should lead that by the end of compulsory schooling, every citizen should be able to recognise and describe the characteristics of the structure, organisation and function of living organisms, in particular those in their immediate surroundings, the role they play in ecosystems, and be able to recognise loss of biodiversity as one of the most serious problems that humanity faces as a consequence of some of its activities (MEC, 2006, 2007a, b).

The invertebrates are specifically approached in the second cycle of elementary education (ages 8/10) and the students are meant to work on their basic characteristics, and how to recognize and classify them. In the first year of compulsory secondary education (ages 12/13) the grouping of living organisms into kingdom, phylum, subphylum, class and order is taught, with an emphasis on taxonomy as a useful instrument in understanding biodiversity (MEC, 
2006, 2007b). However, elementary school textbooks pay little attention to the invertebrates, and an examination of the textbooks used in compulsory secondary education showed that the majority devote the same number of pages, or even fewer, to the group of invertebrates as a whole than to the phylum of chordates or to the subtype of vertebrates, according to the different publishers. Our data also shows that the prospective teachers have not effectively assimilated knowledge about them, and that they begin their teacher training lacking in basic knowledge on animal biodiversity, particularly invertebrates.

Thus, among the reasons for this poor understanding of invertebrates are the limited opportunities the prospective teachers have to observe and interact with a broad range of invertebrate animals in informal learning environments, and the limited development of these contents in the formal science curriculum (Howes, 2008; Yen et al., 2007). These results suggest that the way to teach animal classification must be reconsidered: the teaching of the invertebrates must be expanded and the teaching of the vertebrates improved, so that students can achieve a better understanding of both groups. It suggests that the very limited ability of the prospective teachers to name and to understand animals is due to their background experience rather than their educational curriculum.

Concerning spiders, the future teachers' ideas were meager, and consistent with several misconceptions that are also found in the preliminary research of Urones (2008). This study shows that although all the participants said they were familiar with spiders, the results indicated that the majority have scarce knowledge of them. Specifically, their knowledge of spider morphology and anatomy was superficial: the characteristics they knew best were that they have 8 legs and silk; very few participants were able to describe them or draw them correctly and they confused them with insects and opiliones or mites.

The students erroneously described spiders as "insects," this coincides with what Shepardson (2002) found when researching children's ideas about insects. In their written descriptions they refer to the presence of a stinger, in their drawings drew antennae or proboscis, silk secreted from the mouth, and they responded that they feeding on blood. In our opinion, these characteristics point to an analogical error since they associate the presence of spider venom with wasp stings. The aspect of the mosquito head may also be analogical, since they also bite humans by inserting their proboscis. In our view, this mistake on the part of future teachers is due to the fact that the concept of "insect" is applied to all small-sized ani- 
mals, as if it were a synonym of the term "bug," and not a precise scientific concept. This misclassification would then be a problem of vocabulary which better teacher-student communication could solve. For others, the confusion stems from not knowing the term arthropod well. In the first year of compulsory secondary education the arthropods are introduced as animals with articulated limbs (crustaceans, arachnids, insects and myriapods) and their evolutionary success is discussed. The students do not assimilate the arthropod concept and only remember the term most familiar to them: insect, which they then apply to all "bugs"; without understanding the concept of "insect."

Moreover, many students wrongly thought that some spiders cause diseases, coinciding with what Davey (1994) found, and according to whom a cultural component is the cause. From the scientific point of view, there are no known disease-producing spiders. In our view, besides cultural transmission there is an element of taxonomical confusion involved as well. These responses of prospective teachers, along with the assertion that spiders have a body "round like a ball" and the fact that drew an undivided body, spherical or ovoid in shape, suggests that many of these prospective teachers are confusing spiders with ticks, or mites, important vectors of a number of diseases, including Lymes disease.

The prospective teachers also used some attributes in their descriptions and drawings that do not serve to define spiders and lack taxonomic value: for example, the body color, and the presence of hair. Both concepts have a sensorial origin and are related to the contact they have had with spiders, since in our homes and under rocks the spiders tend to be dark in color. These concepts would be very different if they came into contact with spiders living in vegetation or flowers, among which bright, loud colors predominate (Roberts, 1996). Out of school experiences have made a large contribution to prospective teachers' understanding and knowledge of animals just as Tunnicliffe and Reiss (1999) described in the case of children's learning. Beliefs resulting from personal experience, intuition, and "common sense" lead students to form their own ideas and models, often well before formal instruction.

The prospective teachers in our study were highly influenced by social and anthropomorphic stereotypes. In this study more than half the students gave them 2 eyes. A review of educational material for the pre-school and elementary levels revealed many worksheets and illustrations of spiders with human faces, similar to many toys and decorative objects addressed to adults in general (e.g., http://www.first-school.ws/activities/alpha/s/spider.htm). 
Any student who has not looked at a spider through a magnifying glass in order to be able to see its eyes clearly only has these false images to go by. As in the former case of bipedal spiders, representations used frequently in animal images addressed to children. The origin of this knowledge is analogical and has been a part of the educational processes beginning in pre-school education, both in formal and informal learning (stories, cartoons, etc.). When we examined many of the textbooks and materials written for children we found numerous cases of spiders with big human mouths. We wondered whether our future teachers were reproducing these stereotypes based on material for children (e.g.,

http://www.dltk-teach.com/rhymes/missmuffet/index.htm, http://www.first-school.ws/activities/alpha/s/spider.htm).

The participants showed an almost total absence of positive values and attitudes towards spiders. Not one participant referred to the relations between the natural spider populations in their ecosystems and human beings, or to the effective role spiders play in biological control, which makes them important in agro-ecology, of increasing economic interest in today's society. Their knowledge in this area was scanty and they manifest an anthropocentric view in which the only use animals have for humans is their company, as food, and so on, and not their real ecological characteristics. Spiders, owing to their great diversity and abundance, play an important role in food webs, and in ecosystems, and contribute fundamentally to the stability of the nature and are very good indicators of environmental disturbances.

Our results are consistent with research carried out in different countries and ages, eg. Prokop et al. (2009) suggests that at least $30 \%$ of all participants (14 to 17 years) on a crosscultural comparison (Slovakia and South Africa) are afraid of spiders and showed negative attitudes towards them. At the origin of these negative attitudes towards spiders, as fears and phobias, are a cognitive component and a social component, by cultural differences or personal experiences (Davey, 1994; Jong, Andrea, \& Muris, 1997; Prokop \& Tunnicliffe, 2008). The former is based on direct experience with the object, the students are afraid of animals they do not constantly associate with and do not constantly encounter in daily life (Kellert, 1993), and therefore scientific knowledge should help to rectify it. The social component refers to the social environment, and specifically family influence, which is most important. It is therefore necessary to form attitudes of appreciation and respect for the natural world, and teach habits of respect for all living organisms, including spiders. If information, particularly about dangerous animals, is gleaned from hearsay with no scientific basis, it causes serious 
problems in later educational stages. The place and importance of the environment in the student's cognitive development is great, and when the children cannot reach the sources of correct information, they develop alternative conceptions. This issue must be given sufficient importance in educational programs and textbooks (Cardak, 2009).

The students did not think that spiders could have any type of positive relationship with humankind, except in a few unimportant cases, and this explains why they reject or doubt the need to protect them. All the participants were potential future educators and should have been able to understand that nature conservation requires an understanding of the relationship between all forms of life and human populations, and how scientific understanding of the environment is essential to make us aware of our responsibility towards it. It must be explained to preservice teachers, that, in order to protect the ecological balance, no creature should be killed by humans.

The prospective teachers' anthropocentric view hinders them from understanding that the disappearance of species, even those supposedly the enemies of humans, in the long term can be very damaging to humanity, and many examples can be seen in ecology. The most of the prospective teachers said that spiders do not need any protective measures. These results agree with Knight (2008), who found that U.S. undergraduate students perceive spiders as ugly and have negative attitudes, and this directly affects their perception of species protection. And on the contrary, when trainee teachers were asked about the protection of birds, the majority thought that human intervention is needed to protect endangered bird species (Torkar \& Bajd, 2006).

Many researches, for example, Howes (2008), Kellert (1993), Killermann (1996), Weinburgh (2007), have reported that the use of living animals such as snails, ants, darkling beetles, and spiders, among others, in biology lessons positively influenced students' attitudes and increased their knowledge of animals. Bauhardt (1990) pointed out that it was because the students found working with the living insects more motivating which in turn led to effective learning. The methodology used for teaching animals in both primary and secondary schools, and teacher education centres, should be called into question. Consistent with the argument made by Braun and Reiss (2006), we think that science teaching needs to be complemented by out-of-school science learning that draws on the actual world (e.g., through fieldtrips), the presented world (e.g., in science centres and zoos), and the virtual worlds available through 
information technologies. With a knowledge of arthropods and of spiders in particular, students will learn to respect environmental diversity (Weinburgh 2007). Biology projects at school should also pay particular attention to the social component and contribute to the development of positive attitudes towards all animals.

These results should have implications for teacher training. We propose the following corrective strategies aimed at reducing the possible causes of the problems identified:

Firstly, the way we teach about animals must be reconsidered. We must increase the level of teaching about invertebrates and improve the significance of the vertebrates in the resources used in the classroom. Direct contact with small animals is basic for science education. Understanding is often expected before students have a chance to adequately explore and convince themselves of what they have been told. Ideas are often imposed on students, rather than allowing them to have the opportunity to make sense of something by exploring and developing ideas/models over time. Emphasize on teacher training (kindergarten) elementary school who will be responsible for helping children, most researchs says that the early years are essential to providing core knowledge, skills and understanding of their environment and the living organisms that inhabit it. "Covering" the curriculum without devoting enough time for building true understanding is counterproductive (Stepans 1994).

Secondly, a training context should be provided within which prospective teachers can reflect on their own values and beliefs, with activities such as animal exploration, to help prospective elementary teachers increase their own knowledge of content and improve attitudes, as proposed by Weinburgh (2007). They must be taught the real ecological contribution of animals, using, for example on spiders, information that can be found on the Internet: http://www.sedl.org/scimath/pasopartners/spiders, $\quad$ http://www.iibce.edu.uy/difusion, http://www.pocanticohills.org/spiders/spiders.htm, http://insected.arizona.edu/lessons.htm and avoiding excessively aggressive expressions towards spiders and other animals. Moreover, students must be taught about the role played by animals in the dynamics of our planet, and we should avoid presenting animals exclusively in terms of their utility or direct danger to humankind.

Thirdly, we believe it is necessary to revise teaching materials such as worksheets, illustrations, stories, and so on, given the erroneous and distorted view they frequently give of 
animals, especially taking into account the importance of these materials for approaching science in pre-school education. On the one hand, the illustrations should be modified to present a truer image of the animal, as for example with spiders: in the number of eyes, legs, and body segments, as well as types of movement, colors and habitats. On the other hand, in stories, poems and other texts, part of the plot and even the endings should be changed by including details that reduce the negative impact of these animals.

Finally, we believe that this lack of knowledge and interest in animals probably relates to students' educational as well as social and cultural background. We should offer prospective teachers the opportunity to interact directly with living beings in their natural environments; that way they will discover for themselves many of their previously unknown characteristics (Howes, 2008; Yen et al., 2007) and this could promote an attitudinal change (Brown $\&$ Melear, 2007). We propose that science activities with animals should be more focused on rearing invertebrates and improving children's attitudes and knowledge about them (Prokop et $a l ., 2008)$. Students should carry out direct research on the living organisms around them, particularly invertebrates (e.g. arthropods), in cooperative teams, carefully guided by teachers to ensure full participation and interactions among all in the classroom in order to deepen their understanding of the scientific concepts of life sciences, by emphasizing scientific exploration (Wassermann \& Ivany, 1996).

These interventions will help prospective teachers to realize that they have had a mistaken view of many animals, among them spiders, thus providing a confrontation between their ideas and the reality of the natural world, which will lead them to gain a better knowledge of living beings. Prospective teachers should recognize the importance of fostering awareness in children that humans are a part of nature and for this reason the study of diversity should be complemented by encouraging care and respect for all forms of life, creating a favorable atmosphere for the development of environmental attitudes and behavior that show respect for all elements of nature.

\section{Acknowledgements}

We are very grateful to Diane Garvey for her invaluable help with the English. This research was partially supported by Regional Ministry of Education of Castile and Leon (Spain) (under project SA113A07) and by the Spanish Ministry of Education and Science (through grant SEJ2007-61428/EDUC). 


\section{References}

Ausubel, D.P., Novak, J.D., \& Hanesian, H. (1983). Psicología educativa: un punto de vista cognoscitivo. México: Trillas.

Barrow, L. H. (2002). What Do Elementary Students Know about Insects? Journal of Elementary Science Education, 14(2), 51-56.

Bauhardt, V. M. (1990). Veränderung der Einstellung gegenüber Gliedertieren durch Interaktion mit lebenden Tieren im Biologieunterricht. In W. Killermann (Ed.), Münchner Schriften zur Didaktik der Biologie (Bd. 7), München.

Bell, B., \& Barker, M. (1982). Towards a scientific concept of animal. Journal of Biological Education, 16(3), 197-200.

Biddulph, F. (1982). Primary school children's ideas about spiders. Learning in Science Project (Primary). Working Paper (No.108) of the Science Education Research Unit, University of Waikato, Hamilton N. Z.

Braund, M. (1991). Children's ideas in classifying animals. Journal of Biological Education, 25(2), 103-110.

Braund, M. (1998). Trends in children's concepts of vertebrate and invertebrate. Journal of Biological Education, 32(2), 112-118.

Brown, S., \& Melear, C. (2007). Preservice Teachers' Research Experiences in Scientists' Laboratories. Journal of Science Teacher Education, 18(4), 573-597.

Campanario, J.M. (1998). ¿Quiénes son, qué piensan y qué saben los futuros maestros y profesores de ciencias?: una revisión de estudios recientes. Revista Interuniversitaria de formación del Profesorado, 33, 121-140.

Cardak, O. (2009). Students' ideas about dangerous animals. Asia-Pacific Forum on Science Learning and Teaching, 10(2), 8.

Chen, S.-H. \& Ku, C.-H. (1998). Aboriginal children's alternative conceptions of animals an animal classification. Proceedings of the National Science Council, 8(2), 55-67.

Coddington, J.A., \& Levi, H. W. (1991). Systematics and the evolution of spiders (Araneae). Annual Review of Ecology and Systematics, 22, 565-592.

Davey, G.C.L. (1994). The "Disgusting" Spider: The role of disease and illness in the perpetuation of fear of spiders. Society and Animals, 2(1), 17-25.

Harlen, W. (2003). Enseñanza y aprendizaje de las ciencias. Madrid: MEC \& Ed Morata. 
Howes, E.V. (2008). Educative experiences and early childhood science education: A Deweyan perspective on learning to observe. Teaching and Teacher Education, 24, $536-549$.

Jong, P.J. De, Andrea, H., \& Muris, P. (1997). Spider phobia in children: Disgust and fear before and after treatment. Behaviour Research and Therapy, 35, 559-562.

Karapantsios, T.D., Bouskou, E.I., \& Balouktsis, A.I. (1999). Students' awareness of the urban environment in a small Greek city. The Environmentalist, 19, 305-316.

Kattmann, U. (2001). Aquatics, flyers, creepers and terrestrials - students' conceptions of animal classification. Journal of Biological Education, 35(3), 141-147.

Kellert, S.R. (1993). Values and perceptions of invertebrates. Conservation Biology, 7(4), 845-855.

Killermann, W. (1996). Biology education in Germany: research into the effectiveness of different teaching methods. International Journal of Science Education, 18(3), 333-346

Kindt, M., \& Brosschot, J. (1999). Cognitive bias in spider-phobic children: comparison of a pictorial and a linguistic spider stroop. Journal of Psychopathology and Behavioral Assessment, 21(3), 207-220.

Knight, A.J. (2008) "Bats, snakes and spiders, Oh my!" How aesthetic and negativistic attitudes, and other concepts predict support for species protection. Journal of Environmental Psychology, 28, 94-103.

MEC [Spanish Ministry of Education and Science] (2006). Real Decreto 1513/2006 de enseñanzas mínimas de Educación primaria. B.O.E. 293 (del 8-12-06), 43053-43102 [Available at: http://www.educacion.es/horizontales/iniciativas/desarrollo-loe.html]

MEC (2007a). Real Decreto 1630/2006 de enseñanzas mínimas de segundo ciclo de Educación infantil. B.O.E. 4 (del 4-01-07), 474-482 [Available at: http://www.educacion.es/horizontales/iniciativas/desarrollo-loe.html]

MEC (2007b). Real Decreto 1631/2006 de enseñanzas mínimas de Educación secundaria. B.O.E. 5 (del 5-01-2007), 677-773 [Available at: http://www.educacion.es/horizontales/iniciativas/desarrollo-loe.html]

Melic, A. (2002). Mother spider to devil scorpion: Arachnids in mythology (In Spanish: De madre araña a demonio escorpión: Arácnidos en la mitología). Revista Ibérica de aracnología, 5, 112-124.

Osborne, R., \& Freyberg, P. (Eds.) (1985). Learning in science. The implications of children's science. Auckland, NZ: Heinemann. 
Platnick, N. I. (2010). The world spider catalog, version 10.5. American Museum of Natural History, online at http://research.amnh.org/entomology/spiders/catalog/index.html

Prokop, P. \& Tunnicliffe, S. D. (2008). “Disgusting” animals: Primary school children's attitudes and myths of bats and spiders. Eurasia Journal of Mathematics, Science \& Technology Education, 4(2), 87-97.

Prokop, P., Kubiatko, M., \& Fančovičová, J. (2007). Why do cocks crow? Children's concepts about birds. Research Science Education, 37, 393-405.

Prokop, P., Prokop, M., \& Tunnicliffe, S. D. (2008). Effects of keeping animals as pets on children's concepts of vertebrates and invertebrates. International Journal of Science Education, 30(4), 431-449.

Prokop, P., Tolarovicová, A., Camerik, A.M. \& Peterková, V. (2009) High school student's attitudes towards spiders: A cross- cultural comparison. International Journal of Science Education, First published on: 22 october 2009 (iFirst), doi: 10.1080/09500690903253908.

Redak, R. (2000). Arthropods and multispecies habitat conservation plans: Are we missing something? Environmental Management, 26(1), 97-107.

Roberts, M.J. (1996). Spiders of Britain \& Northern Europe. Collins Field Guide. London: Harper Collins Publishers.

Ruppert, E.E., Fox, R.S., \& Barnes, R.D. (2004). Invertebrate zoology. A functional evolutionary approach. (7th edition). Thomson Brooks/Cole.

Shepardson, D. P. (1997). Of butterflies and beetles. First grader's ways of seeing and talking about insect life cycles. Journal of Research in Science Teaching, 34(9), 873-889.

Shepardson, D.P. (2002). Bugs, butterflies, and spiders: children's understandings about insects. International Journal of Science Education, 24(6), 627-643.

Stepans, J. (1994). Targeting students' science misconceptions. Riverview, FL: Idea Factory, Inc.

Thurston, Grant \& Topping, (2006). La construcción de la comprensión en ciencias naturals de Primaria: una exploración del proceso y sus resultados en los contenidos de la luz y la tierra en el espacio. Electronic Journal of Research in Educational Psychology, $4(1), 1-34$.

Torkar, G. \& Bajd, B. (2006). Trainee teachers' ideas about endangered birds. Journal of Biological Education, 41, 5-8.

Trowbridge, J.E., \& Mintzes, J.J. (1985). Students' alternative conceptions of animals and animal classification. School, Science and Mathematics, 85(4), 304- 316. 
Trowbridge, J.E., \& Mintzes, J.J. (1988). Alternative conceptions in animal classification: A cross-age study. Journal of Research in Science Teaching, 25(7), 545-571.

Tunnicliffe, S., \& Reiss, A. (1999). Learning about skeletons and other organ systems of vertebrate animals. Science Education International, 10(1), 29-33.

Urones, C. (2008). Trainee teachers' concepts about animal diversity and spiders. Boletín Sociedad Entomológica Aragonesa, 42, 507-515 (In Spanish)

Wassermann, S. \& J.W.G. Ivany, (1996). The new teaching elementary science: who's afraid of spiders? New York: Teachers College Press. 2nd Edition.

Weinburgh, M. (2007). The Effect of Tenebrio obscurus on Elementary Preservice Teachers' Content Knowledge, Attitudes, and Self-efficacy. Journal of Science Teacher Education, 18(6), 801-815.

Yen, C.F., Yao, T.W., \& Chiu, Y.C. (2004). Alternative conceptions in animal classification focusing on amphibians and reptiles: A cross-age study. International Journal of Science and Mathematics Education, 2(2), 159-174.

Yen, C.F., Yao, T.W., \& Mintzes, J.J. (2007). Taiwanese students' alternative conceptions of animal biodiversity. International Journal of Science Education, 29(4), 535-553.

Websites:

$<\underline{\text { http://insected.arizona.edu/lessons.htm }}>($ March 26, 2010)

$<$ http://www.dltk-teach.com/rhymes/missmuffet/index.htm $>$ (March 26, 2010)

$<$ http://www.first-school.ws/activities/alpha/s/spider.htm> (March 26, 2010)

$<$ http://www.iibce.edu.uy/difusion> (March 26, 2010)

$<$ http://www.pocanticohills.org/spiders/spiders.htm> (March 26, 2010)

$<$ http://www.sedl.org/scimath/pasopartners/spiders> (March 26, 2010) 